\title{
Thermodynamic Effects of Mesoscale Convective Systems on the Environment over the Eastern Atlantic
}

\author{
By Yi-Leng Chen \\ Department of Meteorology, University of Hawaii, Honolulu, Hawaii 96822 \\ (Manuscript received 9 December 1985, in revised form 9 January 1987)
}

\begin{abstract}
Distributions of composited convective heating and drying vary substantially during the life cycle of six cloud clusters identified by Frank (1978) in Phase III of GATE. Convective heating $\left(Q_{1}-Q_{R}\right)$ and drying $\left(Q_{2}\right)$ begin in the lower troposphere. As cloud clusters mature, intensification of upper level convective heating increases; while below $600 \mathrm{mb}$ drying accompanies decreases in convective heating. The upper level convective heating reaches its peak, when the upper level cloud cover is largest; whereas the $Q_{2}$ maximum at $850 \mathrm{mb}$ coincides with the peak radar echo intensity. The depletion of moist static energy $\left(Q_{1}-Q_{2}-Q_{R}\right)$ in the lower trposphere begins in the growing stage; whereas the upper level heating due to vertical eddy fluxes is most significant in later stages, when deep clouds are prominent.
\end{abstract}

\section{Introduction}

Numerical integrations in fluid dynamical equations are often performed over volumes with grid spacing small enough to resolve the phenomena of interest (grid-scale processes). Effects on grid-scale flow due to small scale motions that have been truncated must be expressed in terms of grid-scale variables. Deep convection, generally organized on the mesoscale $(\sim 100 \mathrm{~km})$ cannot be fully resolved by large-scale models. Incorporation of the effects of deep convection on the large-scale (grid scale) flow in numerical models is a major problem in numerical weather prediction. The most important elements of a cumulus parameterization scheme are the prediction of the rainfall rate (Ogura and Cho, 1973; Yanai et al., 1973; Thompson et al., 1979; Krishnamurti et al., 1980; Lord, 1982; and others) and the determination of the convective heating and drying profiles (Soong and Tao, 1980; Lord, 1982; Song and Frank, 1983; Krishnamurti et al., 1983; Kuo and Anthes, 1984) in terms of largescale variables.

Kuo $(1965,1974)$ assumed that rainfall is proportional to the vertically integrated moisture convergence. Using Kuo's scheme, Krishnamurti et al. (1980) found a close correlation between the observed and predicted precipitation rates. Song and Frank (1983) compared the day-to-day observed and predicted convective heating profiles during the entire period of GATE (GARP ${ }^{1}$ Atlantic Tropical Experiment). They found that the observed convective heating profiles vary more than those predicted by Kuo's scheme which tended to give maximum heating in the midtroposphere. Semiprognostic tests of the Arakawa and Shubert (1974) cumulus parameterization scheme (Lord and Arakawa, 1980; Lord, 1982) suggested that the cloud-work function quasi-equilibrium is a good approximation; the calculated instantaneous precipitation agrees well with radar rainfall estimates. The time-averaged predicted and observed vertical profiles of heating and drying are similar except for slightly more warming and drying in the lower troposphere. Lord (1982) suggested that discrepancies between the predicted and observed heating and drying may be due to the neglect of cumulus-

\footnotetext{
${ }^{1}$ Global Atmospheric Research Program 
scale downdrafts and mesoscale circulations associated with stratiform clouds.

GATE studies revealed that precipitation over the eastern Atlantic was primarily produced by cloud clusters. These were defined (see Tollerud and Esbensen, 1985) as a group of cumulonimbus joined in their mature and dissipating stages by a common cirrus shield about several hundred to one thousand kilometers wide. Some of these cloud clusters consisted of several mesoscale precipitation features (Leary and Houze, 1979a). During the life cycle of cloud clusters, large scale vertical motion was characterized by: (1) lowlevel convergence or its enhancement prior to development; (2) intensification of upward motion at upper levels during development; and (3) decay usually starting at lower levels (Frank, 1978; Ogura et al., 1979). It appears that convective heating and drying profiles depend on the "age" of cloud clusters since both the change and horizontal advection terms in the heat and moisture budgets are small compared to the vertical advection terms (Soong and Tao, 1980).

This paper will demonstrate that convective heating and drying vary substantially during the cloud cluster life cycle, suggesting that effects of the cloud cluster life cycle should be considered in parameterizing moist convection in large scale models with resolvable time scales $\geq 12 \mathrm{~h}$ or spatial scale $\geq 100 \mathrm{~km}$. The vertical distributions of convective heating and drying for all six cloud clusters identified by Frank (1978) in Phase III of GATE were stratified according to stages of the cloud cluster life cycle. A composite analysis revealed similarities in the evolution of convective heating and drying for all cases.

\section{Data}

Thermodynamic data from Phase III of GATE (30 August-18 September 1974) described by Chen and Ogura (1982) and wind data provided by Dr. K. V. Ooyama (see Esbensen et al., 1982) were used. Figure 1 shows the distribution of upper air stations in the $\mathrm{A} / \mathrm{B}$ (outer) and $\mathrm{B}$ (inner) hexagons during Phase III. Hourly radiation and satellite cloud cover data for ten vertical levels from $1000 \mathrm{mb}$ to $100 \mathrm{mb}$ on a $0.5 \times 0.5^{\circ}$ latitude-longitude grid over the GATE A/B-scale ship array have been obtained from Cox and Griffith (1979). The satellite cloud cover was

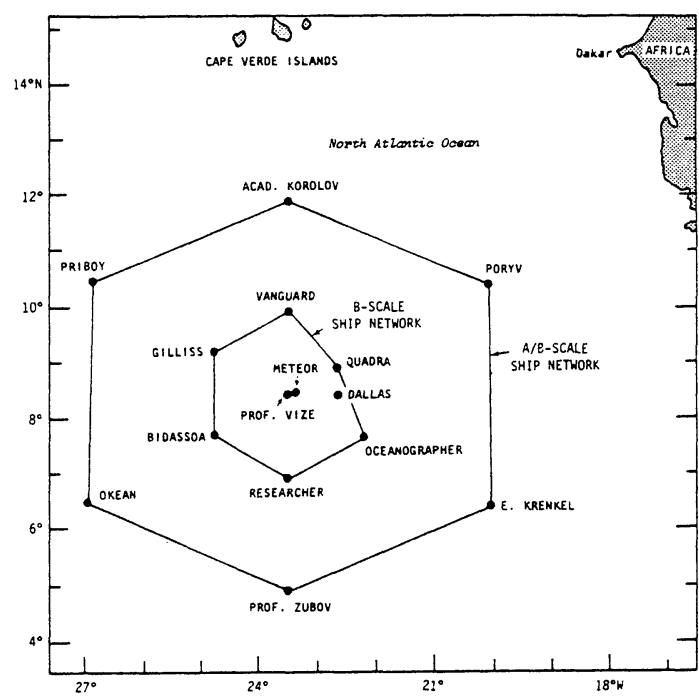

Fig. 1. A/B and B-scale ship arrays for Phase III.

determined from IR cloud-top temperatures and radiosonde temperature profiles. Rainfall rates over the B-scale area estimated from radar data by Hudlow (1979) were also used.

\section{Budget equations}

Denoting the grid point value by an overbar, and the deviation of the true value from the grid point value by a prime, the large-scale heat and moisture equations are:

$$
\begin{aligned}
& Q_{1}-Q_{R}=\frac{\partial \bar{s}}{\partial t}+\nabla \cdot(\bar{V} \bar{s})+\frac{\partial \bar{\omega} \bar{s}}{\partial p}-Q_{R} \\
& =L(\bar{c}-\bar{d}+\overline{d e}-\overline{s u}) \\
& \quad+L_{f}(\overline{d e}-\overline{s u}+\bar{f}-\bar{m})-\frac{\partial \bar{s} \bar{\omega}}{\partial p}-\nabla \cdot\left(\overline{s^{\prime} V^{\prime}}\right),
\end{aligned}
$$

$$
\begin{aligned}
Q_{2}= & -L\left[\frac{\partial \bar{q}}{\partial t}+\nabla \cdot(\bar{V} \bar{q})+\frac{\partial \bar{\omega} \bar{q}}{\partial q}\right] \\
= & L(\bar{c}-\bar{e}+\overline{d e}-\overline{s u}) \\
& +L \frac{\partial \overline{q^{\prime} \omega^{\prime}}}{\partial p}+L \nabla \cdot\left(\overline{q^{\prime} V^{\prime}}\right) \\
Q_{1}-Q_{2}-Q_{R}= & \frac{\partial \bar{h}}{\partial p}+\nabla \cdot(\bar{V} \bar{h})+\frac{\partial \bar{\omega} \bar{h}}{\partial p}-Q_{R} \\
= & L_{f}(\overline{d e}-\overline{s u}+\bar{f}-\bar{m}) \\
& -\frac{\partial \overline{h^{\prime} w^{\prime}}}{\partial p}-\nabla \cdot\left(\overline{h^{\prime} V^{\prime}}\right)
\end{aligned}
$$


where $s=C p T+g Z$ is the dry static energy, $h=$ $C p T+g Z+L q$ the moist static energy, $q$ the water vapor mixing ratio, $L$ the latent heat of condensation, $L_{f}$ the latent heat of freezing, $Q_{R}$ the radiation heating rate, $c$ the rate of condensation, $e$ the rate of evaporation of the liquid water, de the rate of deposition, su the rate of sublimation, $f$ the rate of freezing, and $m$ the rate of melting. The horizontal wind velocity and the vertical $p$-velocity are denoted by $V$ and $\omega ; Q_{1}$ represents the apparent heat source and $Q_{2}$ the apparent moisture sink (Yanai et al., 1973).

The budget equation for hydrometeors, including condensed water and ice particles, in the vertically integrated form can be expressed as:

$$
\begin{aligned}
& \frac{1}{g} \int_{p_{s}}^{p_{T}}\left(\frac{\partial \bar{l}}{\partial t}\right) d p+\frac{1}{g} \int_{p_{s}}^{p_{T}} \nabla \cdot(\bar{V} \bar{l}) d p \\
& \quad+\frac{1}{g} \int_{p_{s}}^{p_{T}} \nabla \cdot\left(\overline{l^{\prime} V^{\prime}}\right) d p+\frac{1}{g} \int_{p_{s}}^{p_{T}} \nabla \cdot\left(\overline{q^{\prime} V^{\prime}}\right) d p \\
& \quad+\left(P_{0}-E_{0}\right)=\frac{1}{g L} \int_{p_{s}}^{p_{T}} Q_{2} d p,
\end{aligned}
$$

where $P_{s}, P_{T}$ are pressure levels at the surface and tropopause, respectively; $\ell$ represents the total hydrometeor content; $E_{0}$ is the evaporation from the ocean surface, and $P_{0}$ is the estimated rainfall rate.

Since the scale of analysis depends on station separation rather than grid spacing, phenomena with sizes smaller or comparable to the $B$-scale ship array such as cumulus clouds or mesoscale circulations associated with stratiform clouds within the cloud clusters cannot be fully resolved by the $B$-scale analyses and are considered as subgrid scale processes. Latent heat due to phase changes involving the ice phase is included in the budget equations since analyses of radar reflectivity data suggested the presence of ice particles in convective cells (Szoke and Zipser, 1986) as well as in stratiform clouds (Leary and Houze, 1979b). However, GATE observations within cloud clusters were insufficient to resolve the contributions of various cloud-scale and mesoscale processes to the large-scale convective heating and drying over the life cycle. Although aircraft data gave the best airflow information within GATE cloud clusters (e.g., Houze and Rappaport, 1984), they have been limited to a few flight levels per observational time period. These limited data require a diagnostic model for quantitative interpretation of the evolution of large-scale convective heating and drying in terms of physical processes within cloud clusters. Horizontal eddy fluxes are retained in the budget equations. Since the $B$-scale array is about the same size as cloud clusters, the detailed airflow within cloud clusters was not fully resolved by the analysis (Esbensen et al., 1982). Also, much heat and moisture detrained from cloud clusters at high levels may be transported outside the $B$-scale array by unresolvable horizontal eddies (Chen, 1985a).

\section{Methods of analysis}

\section{a. Budget calculations}

Using cubic spline under tension, the radiation data and A/B scale and B-scale thermodynamic data were interpolated into 38 levels same as those of the wind data. Horizontal distributions of thermodynamic data were obtained using the same procedures described by Chen and Ogura (1982). Convective heating and drying at 3-h intervals were evaluated from the large scale terms, i.e., from the left-hand sides of Eqs. (1)(3), at every grid point with $0.5^{\circ}$ grid spacing. Under a steady state assumption, Gamache and Houze (1982) used a radiosonde compositing technique to construct three-dimensional kinematic fields associated with a squall line. The spatial resolution is increased because data from several time periods were incorporated into the analysis. A similar procedure was used for a midlatitude squall line by Ogura and Liou (1980). In this study since the primary interest is on the evolution of vertical distributions of convective heating and drying during the life cycle of cloud clusters, area-averaged heating and drying at 3-h intervals were obtained by averaging grid point values within $2^{\circ}$ of the center of the $\mathrm{A} / \mathrm{B}$ ship array.

Frank (1980) discussed systematic errors in upper tropospheric temperature measurements due to solar heating. These introduced spurious time changes of dry static energy. Since the geopotential height was calculated from the hydrostatic equation, errors would be accumulated in the upper troposphere. Above the $400 \mathrm{mb}$ level, relatively large temperature variations with am- 
plitudes of $0.4-0.6^{\circ} \mathrm{C}$ occurred with morning minima and afternoon maxima (Albright et al., 1981). Frank (1980) suggested that the true amplitude of net tropospheric temperature change in the B-scale network is about two-thirds of the observed amplitude. Systematic errors in the dry static energy tendency in the upper troposphere were evaluated from the $Q_{1}-Q_{2}-Q_{R}$ profiles during the periods when deep convection was not vigrous. $Q_{1}-Q_{2}-Q_{R}$ should be small in the upper levels when the deep convection was weak. Frank (1978) identified six major cloud clusters (Day 245, 247, 248, 255, 256, 259) in Phase III. In the $\mathrm{A} / \mathrm{B}$ scale region diurnal variations of $Q_{1}-$ $Q_{2}-Q_{R}$ for days lacking major cloud clusters were composited (Fig. 2). Above the $400 \mathrm{mb}$ level, systematic positive values in the composited $Q_{1}-Q_{2}-Q_{R}$ in the morning accompanied negative values in the late evening. Since deep convection is an important source of $Q_{1}$ $Q_{2}-Q_{R}$ in the upper troposphere (Riehl and Malkus, 1958), the change in $Q_{1}-Q_{2}-Q_{R}$ from positive in the morning to negative appears to be caused by instrumentation errors due to solar heating. To estimate instrumentation errors, the compoisted $Q_{1}-Q_{2}-Q_{R}$ was first decomposed into time mean and deviations from it. Then a three point running mean was applied to the deviations of the composited $Q_{1}-Q_{2}-Q_{R}$ to remove small scale fluctuations. The smoothed values above the $400 \mathrm{mb}$ level are considered as diurnal errors in the dry static energy tendency estimates due to solar heating (Table 1). To compensate for these errors, 80 percent of these values were subtracted from dry static energy tendency for every diurnal cycle. These corrections modified the life cycle composites of $Q_{1}-$ $Q_{R}$ for cloud clusters only slightly.

\section{b. Composite analysis}

Over the eastern Atlantic, cloud clusters are categorized as squall or nonsquall. In satellite imagery, squall clusters grow explosively; and are oval, very bright and fast moving (Martin, 1975). Three of the six identified by Frank (1978) in Phase III were squall clusters (Day 247, 255, 259) as revealed by radar reflectivity data (Leary and Houze, 1979b). After low level convergence triggers convection, isolated convective cells start to grow. During intensification, convective cells

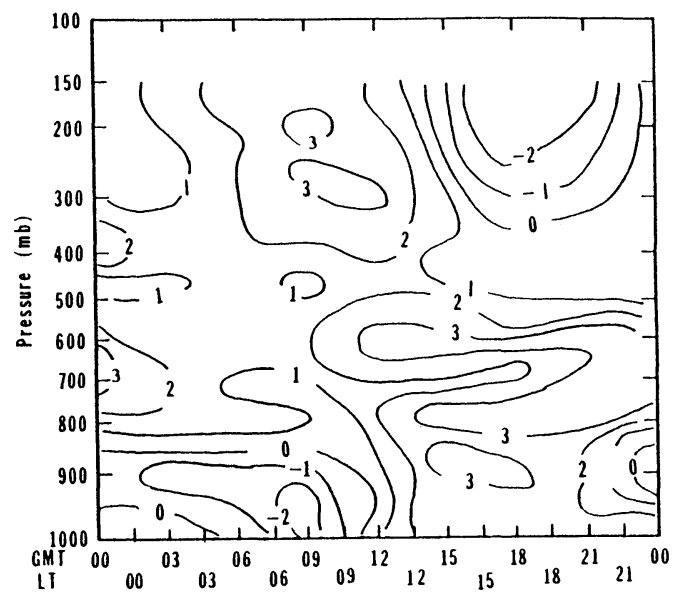

Fig. 2. Diurnal variations of $Q_{1}-Q_{2}-Q_{R}$ in units of ${ }^{\circ} \mathrm{C}$ per day excluding days when major cloud clusters were present in Phase III.

Table 1. Three-point running mean of the deviations of $Q_{1}-Q_{2}-Q_{R}$ from the day mean in units of ${ }^{\circ} \mathrm{C}$ per day excluding days when major cloud clusters were present in Phase III.

\section{GMT (Hour)}

$\begin{array}{rrllllccc}P(\mathrm{mb}) & 00 & 03 & 06 & 09 & 12 & 15 & 18 & 21 \\ 160 & -0.7 & 1.0 & 1.9 & 2.2 & 1.2 & -0.5 & -2.0 & -1.6 \\ 175 & -0.6 & 1.2 & 1.9 & 2.1 & 1.2 & -1.2 & -2.2 & -1.7 \\ 191 & -0.6 & 0.6 & 1.6 & 2.1 & 1.2 & -0.8 & -1.4 & -1.8 \\ 208 & -0.8 & 0.2 & 1.2 & 1.9 & 1.4 & -0.4 & -1.8 & -1.7 \\ 227 & -0.7 & 0.2 & 1.0 & 1.7 & 1.3 & -0.3 & -1.6 & -1.6 \\ 247 & -1.0 & 0.4 & 1.4 & 2.1 & 1.2 & -0.6 & -2.1 & -2.0 \\ 269 & -0.9 & 0.1 & 0.9 & 1.8 & 1.4 & -0.2 & -1.5 & -1.6 \\ 292 & -1.9 & 0.1 & 0.7 & 1.6 & 1.3 & -0.1 & -1.3 & -1.4 \\ 317 & -0.6 & 0.1 & 0.6 & 1.3 & 1.1 & -0.1 & -1.2 & -1.2 \\ 343 & -0.3 & 0.2 & 0.4 & 0.9 & 0.7 & 0.0 & -0.8 & -0.5 \\ 371 & 0.3 & 0.5 & 0.2 & 0.4 & 0.1 & -0.4 & -0.8 & -0.3\end{array}$

grow and merge with new cells which develop between and ahead of existing cells. As clusters mature, these systems comprise convective cells and extensive uniform precipitation associated with upper level anvil-type cirrus. During dissipation, convective cells weaken but horizontally uniform precipitation persists for several hours. Over the life cycle of cloud clusters, the evolution of radar reflectivity is consistent with larger scale vertical motions computed by Frank (1978) and Ogura et al. (1979). Evidence of mesoscale downdrafts below the anvil-type clouds was found in nonsquall (Zipser et al., 1981) as well as in squall clusters (Zipser, 1977; Houze, 1977). 
Houze and Betts (1981) and Ogura (1985) discussed structure and evolution of squall and nonsquall clud clusters.

During squall line occurrences, Frank (1978) found a strong low-level vertical wind shear over the GATE B array. Chen (1985b) showed that the lower troposphere easterly jets observed for all squall clusters were along the leading and southern edges of Saharan air outbreaks (Carlson and Prospero, 1971). Although profiles of zonal wind, relative vorticity and vorticity budget residual differed considerably between squall and nonsquall clusters (Sui and Yanai, 1986), the evolutions of the divergence and vertical motion fields during different stages of the life cycle for squall and nonsquall clusters were remarkably similar (Frank, 1978; Ogura et al., 1979). Similar evolutions in the divergence and vertical motion fields were found for an intense Oklahoma squall line despite greatly differing synoptic-scale settings (Ogura and Chen, 1977). These results suggest a close link between these fields and mesoscale processes after the development of cloud clusters (Frank, 1978; Houze 1982; Tollerud and Esbensen, 1985). Since ver-

Table 2. Cloud cluster classification (after Frank, 1978)

\begin{tabular}{cll} 
Stage & Convection & $\begin{array}{l}\text { Convection } \\
\text { tendency } \\
\text { (next } 3 \mathrm{~h} \text { ) }\end{array}$ \\
\hline 1 & weak & increases \\
2 & moderate & increases \\
3 & strong & increases \\
4 & strong & steady \\
5 & strong & weakens \\
6 & moderate & weakens
\end{tabular}

tical advection terms dominate the left-hand sides of budget equations (1)-(3) compared to the change and horizontal advection terms (Soong and Tao, 1980), there are apparently no qualitative differences in $Q_{1}$ and $Q_{2}$ profiles between squall and nonsquall clusters. In fact, timeaveraged $Q_{1}, Q_{2}$ profiles for three squall and three nonsquall clusters identified by Frank during GATE Phase III were found to be similar (not shown). In this study, these six cloud clusters were used in developing life cycle composites of the vertical distributions of convective heating and drying. Frank's classification scheme based on digitized radar data (Table 2), and Frank's periods used in each stage composite (Table 3) were followed.

Some of these cloud clusters moved away from the center of B-scale array during their life cycle (for example, Day 247). In budget calculations, Kuo and Anthes (1984) and Esbensen and Wang (1984) used quasi-Lagrangian coordinates moving with cloud clusters. However, in this paper the analysis domain is fixed in space. Although the partitioning between the tendency and advection terms for fixed coordinates is different from that for the quasi-Lagrangian coordinates, the convective heating and drying profiles do not depend on the coordinate system chosen. For an individual case, time changes of convective heating and drying profiles in a fixed domain may be partially related to the propagation of clusters, since propagation may produce changes in fractional area coverages both by convective and stratiform clouds over the B-scale area. However, if more cases are used in the life cycle com-

Table 3. Classification of time periods (GMT) for clusters (after Frank, 1978)

\begin{tabular}{cccccccc}
\multicolumn{7}{c}{ Stage } \\
System & Day & 1 & 2 & 3 & 4 & 5 & 6 \\
\hline 1 & 244 & 21 & & & & & \\
& 245 & 00 & 03 & 09,12 & 15 & 18,21 & \\
& 246 & & & & & & 00 \\
2 & 247 & & 09 & 12,15 & & 18,21 & \\
3 & 248 & & 06 & 09 & 12 & 15,18 & 21 \\
4 & 255 & 06 & 09 & 12 & 15 & 18 & 21 \\
5 & 256 & 09 & 12 & 15 & 18,21 & & \\
6 & 258 & 21 & & & & & \\
& 259 & & 00 & 03,06 & $09,12,15,18,21$ & & \\
& 260 & & & & & 00 & 03
\end{tabular}


posite, mean fractional area coverages for both convective and stratiform clouds over a fixed domain for each stage of the life cycle would be more representative. Among cloud clusters, fundamental similarities in the evolution of vertical distributions of convective heating and drying would emerge from the time composite procedures. Random errors in the analysis would be reduced.

\section{Results}

Early in cloud cluster life, convective heating $\left(Q_{1}-Q_{R}\right)$ and drying $\left(Q_{2}\right)$ profiles are greatest near the $850 \mathrm{mb}$ and $950 \mathrm{mb}$ levels, respectively (Figs. 3 and 5). As cloud clusters intensify, peaks in $Q_{1}-Q_{R}$ and $Q_{2}$ profiles shift upward and increase. Later in the life cycle, both convective heating and drying peak at the $430 \mathrm{mb}$ level in agreement with Esbensen and Wang (1984), suggesting the development of an upper level stratiform cloud deck. Apparently, the net condensation within stratiform clouds occurs primarily in the 400-600 mb layer. The shift of maximum convective heating from the lower troposphere to anvil level as cloud clusters mature is consistent with the evolution of vertical motion found by Frank (1978) and Tollerud and Esbensen (1985), and the life cycle aspects of cloud clusters dis-

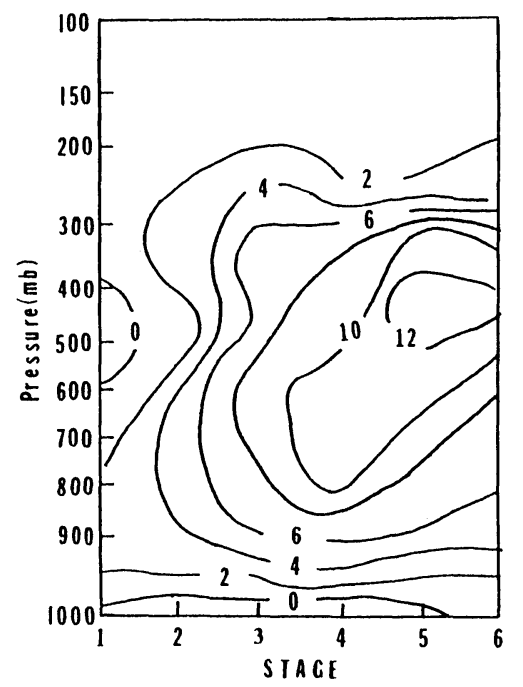

Fig. 3. Convective heating $\left(Q_{1}-Q_{R}\right)$ as a function of stages of cloud cluster life cycle in units of ${ }^{\circ} \mathrm{C}$ per day. Stages after Frank (1978). cussed by Nitta $(1978,1979)$ and Albright et al. (1981). During the growth, the maximum vertical motion near $800 \mathrm{mb}$ with primary divergence at middle levels suggests development of cumulus congestus with the top reaching $500 \mathrm{mb}$ (Fig. 4). In stages five and six, midlevel divergence is replaced by convergence, and this contributes to the large-scale upward motion that maintains the

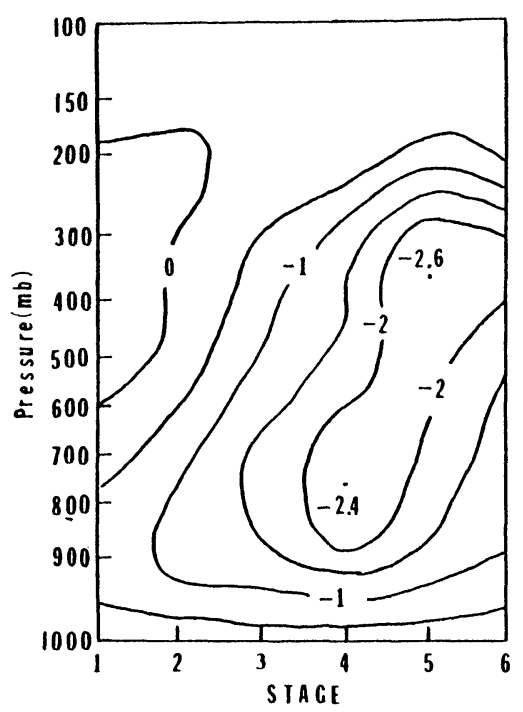

Fig. 4. Same as Figure 3, but for vertical motion in units of microbars per second.

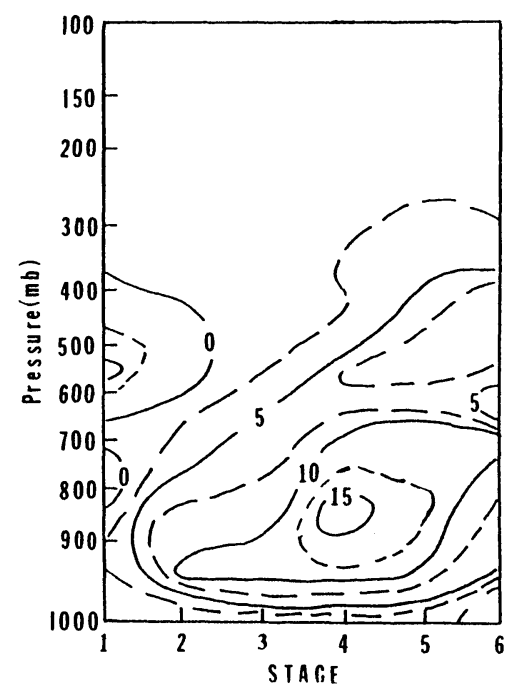

Fig. 5. Same as Figure 3, but for apparent moisture sink $\left(Q_{2}\right)$ in units of ${ }^{\circ} \mathrm{C}$ per day. 
stratiform anvil and weakens upward motion in the lower troposphere. Late stage increases in upper level heating $\left(Q_{1}-Q_{R}\right)$ and drying $\left(Q_{2}\right)$ are accompanied by decreases in lower levels due to the reduction in cumulus cloud populations (Leary, 1984), and the presence of evaporative cooling within the unresolved regions of mesoscale downdraft beneath the stratiform clouds (Houze, 1977; Zipser, 1977). Cooling near the surface, from stages one to five, may be related to the injection of cold cumulus downdraft air to the lowest levels beneath the convective cloud base, and evaporation cooling of the convective rainfall.

In the composited upper level cloud cover averaged over the $2^{\circ}$ radius of the $\mathrm{A} / \mathrm{B}$ array center, the deep cloud populations increase during the growing stages, consistent with increase in the upper level convective heating (Fig. 6). Upper level cloudiness is greatest at stage five, coincident with maximum heating (and maximum vertical motion) at the anvil level. The precipiration from convective cells appears to reach its peak in stage four, when the radar echo intensity becomes steady and weakens in stage five, according to Frank's classification of cloud cluster life cycles. Upper level cloud cover and convective heating increase rapidly with very little change in the area-averaged radar observed rainfall rate between stages four and five (Fig. 6), suggesting that the stratiform precipitation grad-

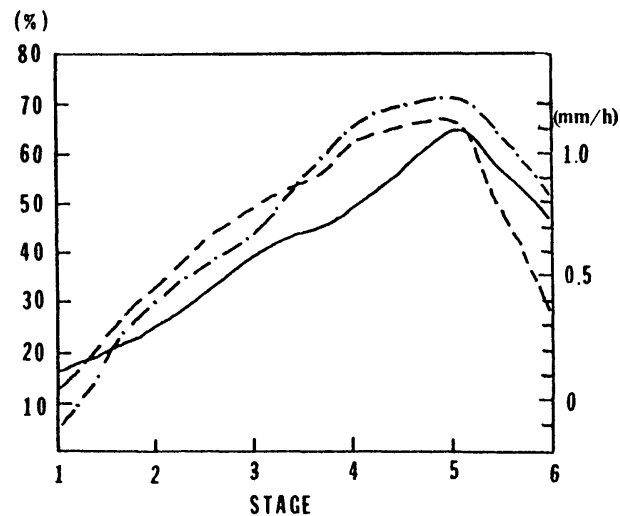

Fig. 6. Same as Figure 3, but for the percentage of cloud populations with tops higher than $400 \mathrm{mb}$ (-); vertically integrated $Q_{2}$ in units of $\mathrm{mmh}^{-1}$ (-.-); radar derived rain rate $(\mathrm{P})$ minus surface evaporation $\left(E_{0}\right)$ in units of $\mathrm{mmh}^{-1}(--)$. ually becomes predominant as cloud clusters mature. These results agree with Nitta's (1979) finding that IR brightness has its peak a few hours after the peak radar observed precipitation rate. Although the phase mean convective heating and drying peak at $550 \mathrm{mb}$ and $850 \mathrm{mb}$, respectively (Thompson et al., 1979), the $Q_{2}$ maximum at $850 \mathrm{mb}$ and the upper level $Q_{1}-Q_{R}$ maximum do not coincide in time. The upper level $Q_{1}-Q_{R}$ and cloudiness both are greatest in stage five; whereas the $Q_{2}$ maximum at $850 \mathrm{mb}$ occurs in stage four, when the radar echo intensity is at its peak. Johnson (1984) showed that in cloud clusters, both the convective heating and drying profiles of cumulus clouds differ from those of stratiform clouds. He suggested that area-averaged convective heating and drying profiles depend on the fractional area coverages of both cumulus and stratiform clouds. During the early stage of cloud clusters, effects on the large scale are primarily due to cumulus clouds in the convective region. However, as cloud clusters mature, the area of stratiform clouds increases. The convective heating and drying due to mesoscale processes associated with stratiform clouds, such as: condensation in mesoscale updrafts above the cloud base, evaporation in mesoscale downdrafts at low levels, and melting at the bright band below $0^{\circ} \mathrm{C}$ then become important (Houze, 1982). The $Q_{2}$ maximum at low levels during the early and growing stages (stages one to four) of cloud clusters with divergence in the middle levels are consistent with the observed weak updrafts within convective cells, $<3-5$ $\mathrm{ms}^{-1}$ (LeMone and Zipser, 1980), and the radar reflectivity profiles reported by Szoke and Zipser (1986). They found modest reflectivities at low levels in these cells, decreasing rapidly with height above the freezing level.

The imbalance in the moist static energy budget $\left(Q_{1}-Q_{2}-Q_{R}\right)$ contains contributions from both latent heat of fusion, $L_{f}(d e-s u+f-m)$, and eddy fluxes [right-hand side of Eq. (3)]. If we consider a quantity, $h_{f}$, which is defined as:

$$
h_{f}=h+L_{f}(q+l \omega),
$$

where $h$ is moist static energy, $q$ the mixing ratio, $l \omega$ the cloud liquid water content; then $h_{f}$ within a parcel is conserved for phase changes involving ice phase. The imbalance in the grid scale $h_{f}$ 
budget at the anvil level is due to eddy fluxes only. Within the upper level clouds, $l \omega$ is of the order of $0.5 \mathrm{~g} / \mathrm{kg}$ (Tao and Simpson, 1984). It appears that $h \approx h_{f}$ in the upper levels, since $L_{f}$ is considerably smaller than $L$ and both $q$ and $l \omega$ are relatively small. Therefore, the residuals of the $h$ budget are close to those of the $h_{f}$ budget in the upper levels. This suggests that eddy fluxes contribute significantly to the imbalance in the $h$ budget in the upper levels. The $Q_{1}-Q_{2}-Q_{R}$ source in the upper troposphere is generally confined to growing and mature stages (stages three to five) of cloud clusters (Fig. 7). Since horizontal eddies are important energy sinks in the upper levels (Chen, 1985a), the $Q_{1}-$ $Q_{2}-Q_{R}$ source there, apparently stems from vertical eddy fluxes. Most moist static energy in the upper levels is deposited in stage five when upper level cloudiness is greatest, indicating the important role played by deep convection. Although these upper level stratiform clouds are based at the middle levels where the moist static energy is least, the high moist static energy air in the lower troposphere is transported upward by the convective updrafts and advected to stratiform clouds in the higher levels (Lo et al., 1982). Gamache and Houze (1983) suggested that mesoscale upward motion in the stratiform cloud of a squall cluster accounts for only $25-40 \%$ of the condensate making up the stratiform cloud;



Fig. 7. Same as Figure 3, but for $Q_{1}$ $Q_{2}-Q_{R}$ in units of ${ }^{\circ} \mathrm{C}$ per day. while the remaining $60-75 \%$ is supplied by horizontal transfer of condensate generated in cumulus clouds to the stratiform region. Convective cells usually last about 1 hour. After their decay, the remnants of convective cells associated with cloud clusters frequently become merged in the anvil clouds (Szoke ad Zipser, 1986). The lag between the low-level maximum in $Q_{1}-Q_{2}-Q_{R}$ sink and the upper level maximum in $Q_{1}-Q_{2}-$ $Q_{R}$ source is much greater than the typical lifetime of convective cells. This indicates that mesoscale circulations, associated with cloud clusters, play an important role in the vertical redistribution of moist static energy in the troposphere.

Vertically integrated $Q_{2}$ [the right-hand side of Eq. (4)] agrees with the composite of the area-averaged hourly radar-derived rainfall (Hudlow, 1979) minus surface evaporation $\left(P_{-}\right.$ $E_{0}$ ), estimated by the bulk aerodynamic method (Chen and Ogura, 1982), throughout most of the life cycle (Fig. 6) except stage six. The time lag between the vertically integrated $Q_{2}$ and the radar-observed precipitation peaks found by Frank (1979) is not evident, in agreement with Ruprecht's (1982) results. The discrepancy between the vertically integrated $Q_{2}$ and radarderived rain rate at stage six may result from the neglect of grid-scale hydrometeor fluxes and contributions of horizontal eddies, as upper level stratiform clouds dissipate.

\section{Conclusion}

The vertical distributions of convective heating and drying undergo substantial variations during the life cycle of cloud clusters. At first, convective heating and drying are greatest in the lower troposphere, and shift upward as cloud clusters mature. Toward the end of the life cycle, both convective heating $\left(Q_{1}-Q_{R}\right)$ and drying $\left(Q_{2}\right)$ peak at $430 \mathrm{mb}$, responding to development of upper level stratiform cloud decks and condensation within them. Decreases in $Q_{1}-Q_{R}$ and $Q_{2}$ in the lower troposphere as upper level $Q_{1}$ $Q_{R}$ and $Q_{2}$ increase and reach their peaks, indicate the presence of evaporative cooling in the mesoscale downdrafts. The upper level $Q_{1}-Q_{R}$ maximum occurs in stage five, when upper level cloudiness is greatest; whereas the $850 \mathrm{mb}$ level $Q_{2}$ maximum occurs in stage four, when the 
radar echo intensity reaches its peak. The vertical eddy transports of moist static energy to the upper levels occur primarily during the growing and mature stages; and are most significant when upper level cloudiness reaches its peak in stage five.

\section{Acknowledgments}

The wind data were provided by Dr. K. V. Ooyama. I am indebted to Professors C. S. Ramage, W.-C. Chiu and T. A. Schroeder for reading the manuscript. Comments and careful review from anonymous reviewers also help the presentation of this paper. Thanks also to Mrs. S. Arita for typing.

\section{References}

Albright, M.D., D.R. Mock, E.E. Recker and R.J. Reed, 1981: A diagnostic study of the diurnal rainfall variation in the GATE B-scale area. J. Atmos. Sci., 28, 1429-1445.

Arakawa, A. and W. Schubert, 1974: Interaction of a cumulus cloud ensemble with the large-scale environment. Part I. J. Atmos. Sci., 31, 674-701.

Carlson, T.N. and J.M. Prospero, 1972: The large-scale movement of Saharan air outbreaks over the northern equatorial Atlantic. J. Appl. Meteor., 11, 283297.

Chen, Y.-L., 1985a: Diagnosis of the net cloud mass flux in GATE. J. Atmos. Sci., 42, 1757-1769.

, 1985b: Tropical squall lines over the eastern Atlantic during GATE. Mon. Wea. Rev., 113, 20152022.

- and Y. Ogura, 1982: Modulation of convective activity by large-scale flow patterns observed in GATE. J. Atmos. Sci., 39, 1260-1279.

Cox, S.K. and K.T. Griffith, 1979: Estimates of radiative divergence during Phase III of the GARP Atlantic Tropical Experiment. Part I: Methodology. J. Atmos. Sci., 36, 576-585.

Esbensen, S.K. and J.-T. Wang, 1984: Heat budget analysis and the synoptic environment of GATE cloud clusters. Preprints 15th Conf. on Hurricane and Tropical Meteorology, Miami, Amer. Meteor. Soc., 455-460.

—, E.I. Tollerud and J.-H. Chu, 1982: Cloudcluster-scale circulations and the vorticity budget of synoptic-scale waves over the eastern Atlantic intertropical convergence zone. Mon. Wea. Rev., 110, 1677-1692.

Frank, W.M., 1978: The life cycles of GATE convective systems. J. Atmos. Sci., 35, 1256-1264.

- 1979: Individual time period analyses over the GATE ship array. Mon. Wea. Rev., 107, 16001616.

1980: Modulations of the net tropospheric temperature during GATE. J. Atmos. Sci., 37 $1056-1064$

Gamache, J.F. and R.A. Houze, Jr., 1982: Mesoscale air motions associated with a tropical squall line. Mon. Wea. Rev., 110, 118-135.

and - 1983: Water budget of a mesoscale convective system in the tropics. J. Atmos. Sci., 40, 1835-1850.

Houze, R.A. Jr., 1977: Structure and dynamics of a tropical squall-line system. Mon. Wea. Rev., 105, $1540-1567$. - and A.K. Betts, 1981: Convection in GATE. Rev. Geophys. Space Phys., 19, 541-576.

- and E.N. Rappaport, 1984: Air motions and precipitation structure of an early summer squall line over the eastern tropical Atlantic. J. Atmos. Sci., 41, 553-574.

Hudlow, M.D., 1979: Mean rainfall patterns for the three phases of GATE. J. Appl. Meteor., 18, 16561665.

Johnson, R.A., 1984: Partitioning tropical heat and moisture budgets into cumulus and mesoscale components: Implication for cumulus parameterization. Mon. Wea. Rev., 112, 1590-1601.

Krishnamurti, T.N., H.-L. Pan, R.J. Pasch and J. Molinari, 1980: Cumulus parameterization and rainfall rates, I. Mon. Wea. Rev., 108, 465-472.

, S. Low-Nam and R. Pasch, 1983: Cumulus parameterization and rainfall rates, II. Mon. Wea. Rev., 111, 815-828.

Kuo, H.-L., 1965: On formation and intensification of tropical cyclone through latent heat release by cumulus convection. J. Atmos. Sci., 22, 40-63.

, 1974: Further studies of the parameterization of the effect of cumulus convection on largescale flow. J. Atmos. Sci., 31, 1232-1240.

Kuo, Y.-H. and R.A. Anthes, 1984: Mesoscale budgets of heat and moisture in a convective system over the central United States. Mon. Wea. Rev., 112, 1482 1497.

Leary, C.A., 1984: Precipitation structure of the cloud clusters in a tropical easterly wave. Mon. Wea. Rev., 112, 313-325.

- and R.A. Houze, Jr., 1979a: The structure and evolution of convection in a tropical cloud cluster. J. Atmos. Sci., 36, 437-457.

and $-1979 \mathrm{~b}$ : Melting and evaporation of hydrometeors in precipitation from the anvi clouds of deep tropical convection. J. Atmos. Sci., $36,669-679$.

LeMone, M.A. and E.J. Zipser, 1980: Cumulonimbus vertical velocity events in GATE. Part I: Diameter, intensity, and mass flux. J. Atmos Sci., 37, 24442457.

Lo, C.S., W.R. Barchet and D.W. Martin, 1982: Vertical mass transport in cumulonimbus clouds on Day 261 of GATE. Mon. Wea. Rev., 110, 1994-2004.

Lord, S.J., 1982: Interaction of a cumulus cloud ensemble with the large-scale environment. Part III: 
Semi-prognostic test of the Arakawa-Schubert cumulus parameterization. J. Atmos. Sci., 39, 88-103. and A. Arakawa, 1980: Interaction of a cumulus cloud ensemble with the large-scale environment. Part II. J. Atmos. Sci., 37, 2677-2692.

Martin, D.W., 1975: Characteristics of West African and Atlantic cloud clusters. GATE Rep. No. 14. Secretariat of the WMO, ICSU/WMO, Case Postale No. 5, CH-1211 Geneva 20, Switzerland, 182-192.

Nitta, T., 1978: A diagnostic study of interaction of cumulus updrafts and downdrafts with large-scale motions in GATE. J. Meteor. Soc. Japan, 56, 232242.

1979: On the comparison of computed cloud mass flux with observations over the GATE area. J. Meteor. Soc. Japan, 57, 474-477.

Ogura, Y., 1985: Tropical convection. Chap. 8. Thunderstorm morphology and dynamics, Vol. 2 (E. Kessler, ed.), Univ. of Oklahoma Press.

and H.-R. Cho, 1973: Diagnostic determination of cumulus cloud populations from observed large-scale variables. J. Atmos. Sci., 30, 1276-1286.

- and Y.-L. Chen, 1977: A life history of an intense mesoscale convective storm in Oklahoma. $J$. Atmos. Sci., 34, 1458-1476.

— , , J. Russell and S.-T. Soong, 1979: On the formation of organized convective systems observed over the eastern Atlantic. Mon. Wea. Rev., 105, 413-420.

and M.-T. Liou, 1980: The structure of a midlatitude squall line: A case study. J. Atmos. Sci., 37, 533-567.

Riehl, H. and J.S. Malkus, 1958: On the heat balance in the equatorial trough zone. Geophysica (Helsinki), 6, 503-539.

Ruprecht, E., 1982: An investigation of tropical cloud cluster over the GATE area. Part I: The environmental fields of cloud ensembles within the cloud clusters. Beitr. Phys. Atmosph., 55, 61-78.

Song, J.L. and W.M. Frank, 1983: Relationships between deep convection and large-scale processes during GATE. Mon. Wea. Rev., 111, 2145-2160.

Soong, S.-T. and W.-K. Tao, 1980: Response of deep tropical cumulus clouds to mesoscale processes. $J$. Atmos. Sci., 37, 2116-2034.

Sui, C.-H. and M. Yanai, 1986: Cumulus ensemble effects on the large-scale vorticity and momentum fields of GATE. Part I: Observational evidence. $J$. Atmos. Sci., 43, 1618-1642.

Szoke, E.J. and E.J. Zipser, 1986: A radar study of convective cells in mesoscale systems in GATE. Part II: Life cycles of convective cells. J. Atmos. Sci., 43, 199-218.

Tao, W.-K. and J. Simpson, 1984: Cloud interactions and merging: Numerical simulations. J. Atmos. Sci., 41, 2901-2917.

Thompson, R.M., S.W. Payne, E.E. Recker and R.J. Reed, 1979: Structure and properties of synopticscale wave disturbances in the Intertropical Convergence Zone of the eastern Atlantic. J. Atmos. Sci., 36, 53-72.

Tollerud, E.I. and S.K. Esbensen, 1985: A composite life cycle of nonsquall mesoscale convective systems over the tropical ocean. Part I: Kinematic fields. $J$. Atmos. Sci., 42, 823-837.

Yanai, M., S. Esbensen and J.-H. Chu, 1973: Determination of bulk properties of tropical cloud clusters from heat and moisture budgets. J. Atmos. Sci., 33, 976-991.

Zipser, E.J., 1977: Mesoscale and convective-scale downdrafts as distinct components of squall-line circulation. Mon. Wea. Rev., 105, 1568-1589. , R.J. Meitin and M.A. LeMone, 1981: Mesoscale motion fields associated with a slowly moving GATE convective band. J. Atmos. Sci., 38, 17251750 .

\title{
東大西洋上における中規模対流系が周囲に及ぼす熱力学的効果
}

\author{
Yi-Leng Chen \\ (ハワイ大学気象学教室)
}

GATEの Phase III 期間中の六つのクラウド・クラスターについて Frank (1978) による分類に基づ くライフ・サイクルの合成結果は, 積雲による加熱と乾燥化が 1 サイクルの間に大きく変化することを 示す。積雲による加熱 $\left(Q_{1}-Q_{R}\right)$ および乾燥化 $\left(Q_{2}\right)$ は下部対流圏において始まる。クラウド・クラス 夕一が成熟するにつれ上部対流圏の加熱は增大し, 一方 $600 \mathrm{mb}$ 面以下では乾燥化と積雲による加 熱の減少がみられる。上層の積雲加熱の最大は上層雲量の最大時にみられ， $Q_{2}$ の値の最大はレ一ダ・エ コ一強度の最大時にみられる。湿潤静力学エネルギー $\left(Q_{1}-Q_{2}-Q_{R}\right)$ の下部対流圈における減少は積雲 系の成長期に始まる。一方上層においては背の高い積雲が支配的となるより後の段階で, 鉛直方向の渦 輸送による加熱が重要な要素となる。 